\title{
Gastrointestinal stromal tumors (GISTs) of the colon
}

\author{
F. Macías-García ${ }^{1,4}$, P. Parada ${ }^{2}$, L. Martínez-Lesquereux ${ }^{2}$, E. Pintos ${ }^{3}$, M. Fraga ${ }^{3}$ \\ and J. E. Domínguez-Muñoz ${ }^{1,4}$ \\ Departments of ${ }^{\prime}$ Gastroenterology, ${ }^{2}$ Digestive Surgery, ${ }^{3}$ Pathology, and ${ }^{4}$ Foundation for Research in Digestive Diseases \\ (FIENAD). Hospital Universitario de Santiago de Compostela. A Coruña, Spain
}

\begin{abstract}
Gastrointestinal stromal tumors (GISTs) are the most common mesenchymal tumors of the gastrointestinal (GI) tract. Although they may arise anywhere of GI tract, colonic presentation is infrequent. We report 2 new cases of colonic GISTs localized at descending and sigmoid colon. Endoscopic biopsies were diagnostic for GISTs and no distant metastasis were observed. Both cases underwent resective surgery as the only treatment. No recurrence was observed during the follow-up period. In this clinical note we review the diagnosis, management and therapeutical options in colonic GISTs, according to literature. KIT immunoreactivity is the base for diagnosis. Risk of malignancy is based on the primary tumor diameter and the mitotic count. Anatomic localization is not an independent prognostic factor. Surgery is the standard treatment for localized primary disease and imatinib is indicated if metastatic or unresectable GISTs.
\end{abstract}

Key words: Colon. GIST. Gastrointestinal stromal tumors.

\section{RESUMEN}

Los tumores del estroma gastrointestinal (GIST) son los tumores mesenquimales más comunes del tracto gastrointestinal (GI). Aunque pueden aparecer en cualquier localización del tracto GI, el colon no es una ubicación frecuente. Presentamos 2 nuevos casos de GIST de colon localizados en el colon descendente y el sigma. El diagnóstico histológico se obtuvo mediante biopsias endoscópicas. En ambos casos se realizó cirugía resectiva como único tratamiento. No se objetivó afectación metastásica en ningún caso. Tampoco se observó recurrencia durante el periodo de seguimiento. En esta nota clínica hemos revisado el diagnóstico, manejo y opciones terapéuticas en los GIST de colon. La inmunorreactividad para el c-kit es la clave para el diagnóstico. El riesgo de malignización se basa en el diámetro tumoral y el índice mitótico. La localización anatómica no parece ser un factor pronóstico independiente. La cirugía supone el tratamiento estándar en caso

Received: 27-01-10

Accepted: 18-02-10.

Correspondence: Fernando Macías García. Servicio de Gastroenterología. Hospital Universitario de Santiago de Compostela. C/ Choupana, s/n. 15706 Santiago de Compostela, A Coruña. Spain. e-mail: fmacgar@yahoo.es de enfermedad localizada, mientras que el imatinib está indicado en los GIST irresecables o con afectación metastásica.

Palabras clave: Colon. GIST. Tumores del estroma gastrointestinal.

Macías-García F, Parada P, Martínez-Lesquereux L, Pintos E, Fraga M, Domínguez-Muñoz JE. Gastrointestinal stromal tumors (GISTs) of the colon. Rev Esp Enferm Dig 2010; 102: 388-390.

\section{INTRODUCTION}

Gastrointestinal stromal tumors (GISTs) are the most common mesenchymal tumors of the gastrointestinal tract. In this article, we describe two GISTs at infrequent localization, the descending and sigmoid colon.

\section{CASE REPORT 1}

An 81 year-old-woman, without relevant medical history, was admitted at our institution because of severe hematochezia $(\mathrm{Hb} 7.9 \mathrm{~g} / \mathrm{dL})$. Upper endoscopy showed no lesions. After hemodynamic stabilization a colonoscopy was performed showing a $12 \mathrm{~mm}$, submucosal and ulcerated bleeding lesion in the descending colon, inside a large diverticulum (Fig. 1A). Barium xray showed duplication in the descending colon, simulating a large diverticulum, with a fixed lesion on the top edge (Fig. 1B). An abdominal-CT showed no other significant lesions. Endoscopic biopsies were diagnostic of colonic GIST.

At this point patient was evaluated for surgery, so laparoscopic sigmoid resection was conducted. Resected specimen contained a $32 \times 30 \mathrm{~mm}$ colonic duplication 

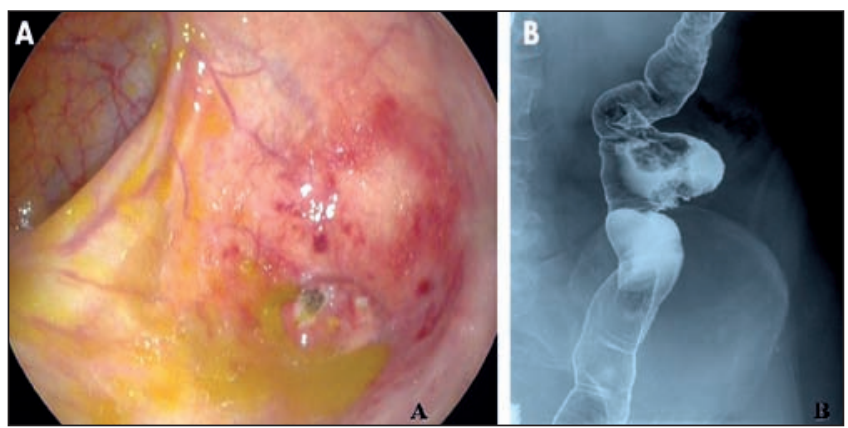

Fig. 1. A. Endoscopic picture showing an ulcerated, submucosal lesion in the descending colon. B. Barium x-ray showing a colonic duplication, simulating a large diverticulum, with a fixed lesion on the top edge.

with a gray, hard nodule of $12 \times 7 \mathrm{~mm}$ (Fig. 2A). Histologically, this nodule was a submucosal, calcified, spindle-cell GIST (c-kit +, CD34 +) (Fig. 2B-C). Mitotic count was $<5 / 50$ high-power field (HPF). Patient has remained asymptomatic 7 months after surgery.
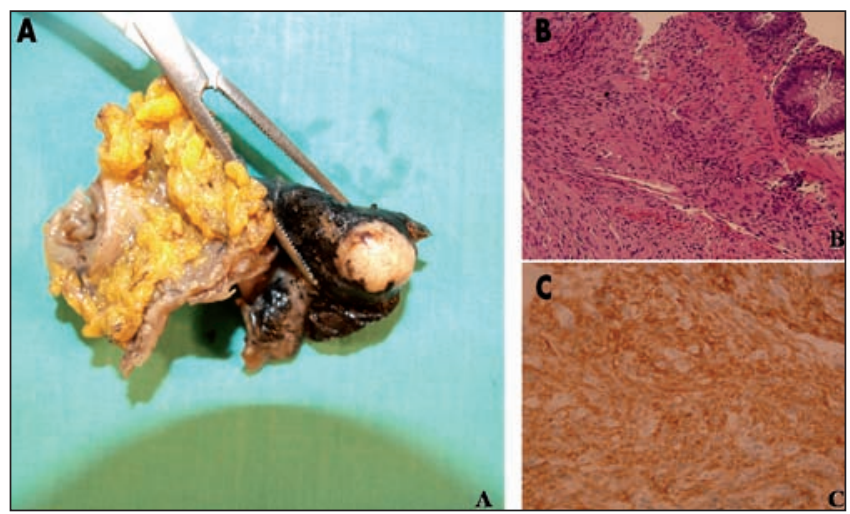

Fig. 2. A. Resected specimen containing a $32 \times 30 \mathrm{~mm}$ colonic duplication with a gray, hard nodule of $12 \times 7 \mathrm{~mm}$. B. Hematoxylin-eosin at 20 magnification (20x), showing a submucosal spindle-cell tumor. C. KIT immunoreactivity at 40 magnification (40x).

\section{CASE REPORT 2}

The case of a 74-year-old male with ischemic heart disease and hypertension who suffered rectal bleeding is presented. Colonoscopy was performed showing a partial stenosing, submucosal and ulcerated mass at $20 \mathrm{~cm}$ from the anal margin. Barium $x$-ray showed an intraluminal infiltrating tumor at the sigmoid loop (Fig. 3A). Thorax and abdominal-CT also showed a concentric and asymmetric wall thickening in distal third of sigma (Fig. 3B); no adenopathy or distant metastases were observed. Histological diagnosis of endoscopic biopsies was sigmoid GIST, so patient underwent a laparoscopic sigmoidectomy. Resected sigmoid specimen contained a whitish,
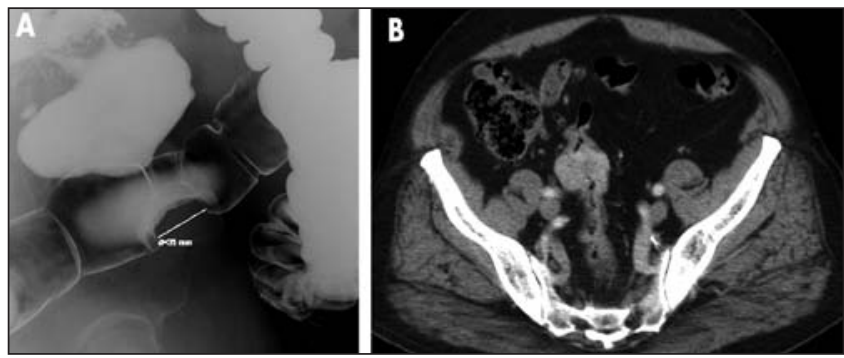

Fig. 3. A. Intraluminal infiltrating tumor at the sigmoid loop at barium $\mathrm{x}$-ray. B. Abdominal-CT showing a concentric and asymmetric wall thickening in distal third of sigma.

bad-defined, central ulcerated lesion of 45 x $40 \mathrm{~mm}$, affecting the entire bowel wall. Immunohistochemistry showed intense positivity of neoplastic cells for c-kit (Fig. 4). Mitotic count was < 5/50 HPF. Isolated lymph nodes showed no evidence of neoplastic infiltration $(0 /$ 10). Final histological diagnosis was spindle-cell GIST. Patient has remained asymptomatic 18 months after surgery.

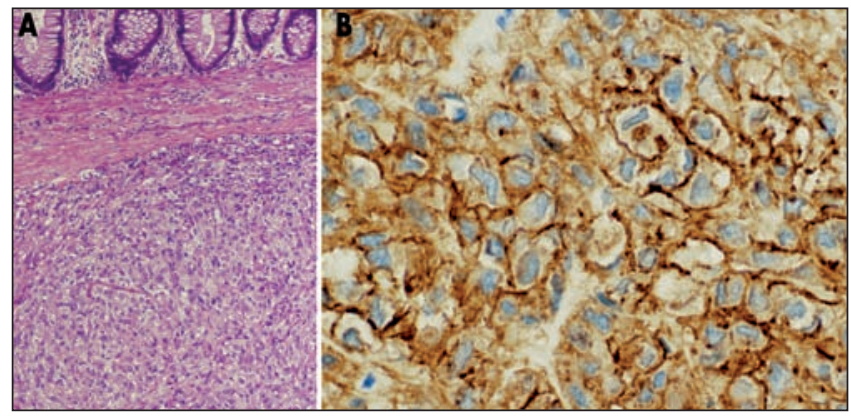

Fig. 4. A. Hematoxylin-eosin at 10 magnification (10x), showing a submucosal spindle-cell tumor. B. KIT immunoreactivity at 40 magnification (40x).

\section{DISCUSSION}

GISTs are mesenchymal tumors originated from interstitial cells of Cajal, and may arise anywhere in the gastrointestinal tract (GI). GISTs are most common in the stomach $(60-70 \%)$, followed by the small intestine (20$25 \%$ ). Colorectal GISTs are rare, frequency being reported at approximately $5 \%$ (1). Recently, they have also been described in extra-GI locations, principally mesentery, omentum, and retroperitoneum (2).

Histological subtypes of GISTs include spindle, epithelioid or mixed-cell tumors. They may be smooth or multinodular contour, containing central areas of hemorrhage, cystic change, necrosis or calcification. Circumferential aneurysmal dilatation of the affected colonic segment has also been described (3). 
Alimentary tract duplications are infrequent developmental anomalies, and the colon is the least common site (6-8\%). Malignant degeneration of duplication cysts in adult patients has previously been described (4), so resection is indicated when a duplication cyst is suspected in an adult. In this sense, another case of colonic GIST arising in a duplication cyst has been recently described (5).

GISTs are usually slow growing lesions, and are often incidentally discovered. Tumor size, location and growth pattern are associated with symptomatic presentation (6). Tumors smaller than $2 \mathrm{~cm}$ are often asymptomatic, usually limited to the colonic wall and appearing as submucosal masses in endoscopic studies. Bleeding due to mucosal ulceration is the most common complication (7).

Immunohistochemically, GISTs are usually positive for KIT (CD117), a transmembrane receptor that is normally expressed on the myenteric plexus of the normal adult, among others tissues (8). Approximately $70 \%$ of GISTs coexpress CD34, and they also may be positive for smooth muscle actin and rarely for desmin and S-100 protein. However, the term GIST is only applied to gastrointestinal mesenchymal neoplasms wich are c-kit positive, with rare exceptions.

Risk of malignancy is based on the primary tumor diameter and the mitotic count. A mitotic index over 5 per 50 high-power field (HPF) or size more than $5 \mathrm{~cm}$ are considered as unfavourable prognostic factors (9). Anatomic location has been previously proposed as a prognostic factor independent of tumor size or mitotic rate. In this sense, small bowel tumors have been associated with the worst prognosis (10), while other authors have regarded most esophageal and colonic lesions as malignant (1). Unfortunately, tumor localization is not reliable in predicting outcome for each individual case.

Because of some GISTs can recur or metastasize despite a histologically benign appearance, GISTs have been stratified into very low, low, intermediate and high risk categories according to Fletcher criteria (9) (tumor size and mitotic count). Actually, an indefinite follow up period has been suggested.

Surgery is the standard treatment for localized primary disease without metastatic involvement, with a 5-year survival range from 45 to $65 \%$ (11). Endoscopic resection could be an option if technically feasible by tumor size or location (12).

Liver and peritoneum are the most common metastatic sites in malignant GISTs. Lymph node metastases are very uncommon. Imatinib ${ }^{\circledR}$, a tyrosine kinase inhibitor, has been used with good results in metastatic or unresectable GISTs (13).
Both cases we have presented had good prognosis according to Fletcher criteria: first case had very low risk of aggressive behavior ( $<5 / 50 \mathrm{HPF}$ ) and the second case had low risk of aggressive behavior (size $<5 \mathrm{~cm}$ and mitotic count $<5 / 50$ HPF). Surgical resection was performed as the only treatment. Both patients have remained asymptomatic several months after surgery (7 and 18 months) and no recurrence has been observed.

\section{REFERENCES}

1. Miettinen M, Lasota J. Gastrointestinal stromal tumors-definition, clinical, histological, immunohistochemical and molecular genetic features and differential diagnosis. Virchows Arch 2001; 438: 1-12.

2. Reith JD, Goldblum JR, Lyles RH, Weiss SW. Extragastrointestinal (soft tissue) stromal tumors: an analysis of 48 cases with emphasis on histologic predictors of outcome. Mod Pathol 200; 13: 577-85.

3. Miettinen M, Sarlomo-Rikala M, Sobin LH, Lasota J. Gastrointestinal stromal tumors and leiomyosarcomas in the colon: a clinicopathologic, immunohistochemical, and molecular genetic study of 44 cases. Am J Surg Pathol 2000; 24: 1339-52.

4. Inoue $\mathrm{Y}$, Nakamura $\mathrm{H}$. Adenocarcinoma arising in colonic duplication cysts with calcification: CT findings of two cases. Abdom Imaging 1998; 23: 135-7.

5. Van Rompuy A, Lannoo M, D'hondt M, D'Hoore A, Geboes K. Gastrointestinal stromal tumor (GIST) arising in a colonic duplication cyst: Case report. Colorectal Dis 2009 Oct 30. [Epub ahead of print]

6. DeMatteo RP, Lewis JJ, Leung D, Mudan SS, Woodruff JM, Brennan MF. Two hundred gastrointestinal stromal tumors: recurrence patterns and prognostic factors for survival. Ann Surg 2000; 231: 51-8.

7. De Francisco R, Díaz G, Cadahía V, Velázquez RF, Giganto F, González O, et al. Lower GI bleeding secondary to a stromal rectal tumor (rectal GIST). Rev Esp Enferm Dig 2006; 98: 387-9.

8. Tsuura Y, Hiraki H, Watanabe K, Igarashi S, Shimamura K, Fukuda $\mathrm{T}$, et al. Preferential localization of c-KIT product in tissue mast cells, basal cells of skin, epithelial cells of breast, small cell lung carcinoma and seminoma/dysgerminoma in humans: immunohistochemical study on formalin-fixed, paraffin-embedded tissues. Virchows Arch 1994; 424: 135-41.

9. Fletcher CD, Berman JJ, Corless C, Gorstein F, Lasota J, Longley BJ, et al. Diagnosis of gastrointestinal stromal tumors: a consensus approach. Hum Pathol 2002; 33: 459-65.

10. Emory TS, Sobin LH, Lukes L, Lee DH, O’Leary TJ. Prognosis of gastrointestinal smooth muscle (stromal) tumors: dependence on anatomic site. Am J Surg Pathol 1999; 23: 82-7.

11. Blay JY, Bonvalot S, Casali P, Choi H, Debiec-Richter M, Dei Tos AP, et al.; GIST consensus meeting panelists. Consensus meeting for the management of gastrointestinal stromal tumors. Report of the GIST Consensus Conference of 20-21 March 2004, under the auspices of ESMO. Ann Oncol 2005; 16: 566-78.

12. Ledo-Rodriguez A, Ulla-Rocha JL, Baltar-Arias R, Vázquez-Rodríguez S, Díaz-Saa W, et al. Endoscopic resection of rectal gastrointestinal stromal tumor (GIST) using band ligation. Rev Esp Enferm Dig 2009; 101: 870-1.

13. Van Oosterom AT, Judson I, Verweij J, Stroobants S, donato di Paola E, Dimitrijevic S, et al.; European Organization for Research and Treatment of Cancer Soft Tissue and Bone Sarcoma Group. Safety and efficacy of imatinib (STI571) in metastatic gastrointestinal stromal tumours: a phase I study. Lancet 2001; 358: 1421-3. 